\title{
Use of Negative Pressure Wound Therapy after Endovascular Revascularization in a Patient with Diabetic Foot Syndrome Complicated by Sepsis
}

\author{
Krzysztof Karaś, Krzysztof Wachal, Tomasz Kościński, Grzegorz Oszkinis
}

\section{CASE REPORT}

\begin{abstract}
We present a case report of a patient suffering from Diabetic Foot Syndrome (DFS) of ischemic etiology. The patient developed toe and dorsal foot tissue necrosis, underwent a revascularization procedure and subsequently amputation of the necrotic tissues. The patient was treated with vacuum therapy. During the hospitalization, despite microbial monitoring of the wound and use of wide spectrum antibiotics according to antimicrobial susceptibility testing (AST), a generalization of the infection occurred and septic shock symptoms followed what in the end resulted in high limb amputation.
\end{abstract}

Keywords-V.A.C., Diabetic Foot Syndrome, lower limb angioplasty, sepsis, septic shock.

\section{INTRODUCTION}

D IABETES, aside from obesity, arterial hypertension, and chronic obstructive pulmonary disease, is one of the most prevalent diseases. It is estimated that in Europe 2$5 \%$ of the general population suffers from diabetes. In some world regions, the disease has reached an epidemic status. 1 It often develops asymptomatically due to deep ischemia of the extremities and disturbance of pain sensation, caused by nervous system impairment.

Every week 100 people with DFS lose a foot due to complicated ulcerations and the frequency of amputations caused by non-healing ulcers or necrosis is $60-85 \%[2]$ International Diabetes Federation (IDF) estimates that 382 million people suffer from diabetes all over the world, including 3 million in Poland alone. Every 6 seconds a person dies due to complications of diabetes. $\frac{3}{3}$ According to Polish Diabetic Association, Poland is in the group of countries performing the highest number of extremity amputations, and additionally 30,000 patients die annually due to diabetes.

DFS is the result of a poorly managed diabetes. We recognize neuropathic, vascular and mixed forms of DFS. According

Manuscript received 03.04.2015; revised 21.04.2015. No conflict of interest Author affiliations: Surgical Department of the Public Hospital in Gniezno, ul. 3 Maja, 37 62-200, Gniezno, (KK); General and Vascular Surgery Clinic of the Poznan University of Medical Sciences ul. Długa 1/2, 61-848, Poznan (KW, GO); Department of General, Endocrinological and Oncologic Surgery of the Poznan University of Medical Sciences, ul. Przybyszewskiego 49, 60355, Poznań, (KK, TK)

*Correspondence to: Krzysztof Karaś, Surgical and Urology Ward, ZOZ Gniezno, ul. 3 Maja 37, 62-200, Gniezno, POLAND. Cell phone: +48 501 736 002, e-mail: kkaras85@gmail.com.

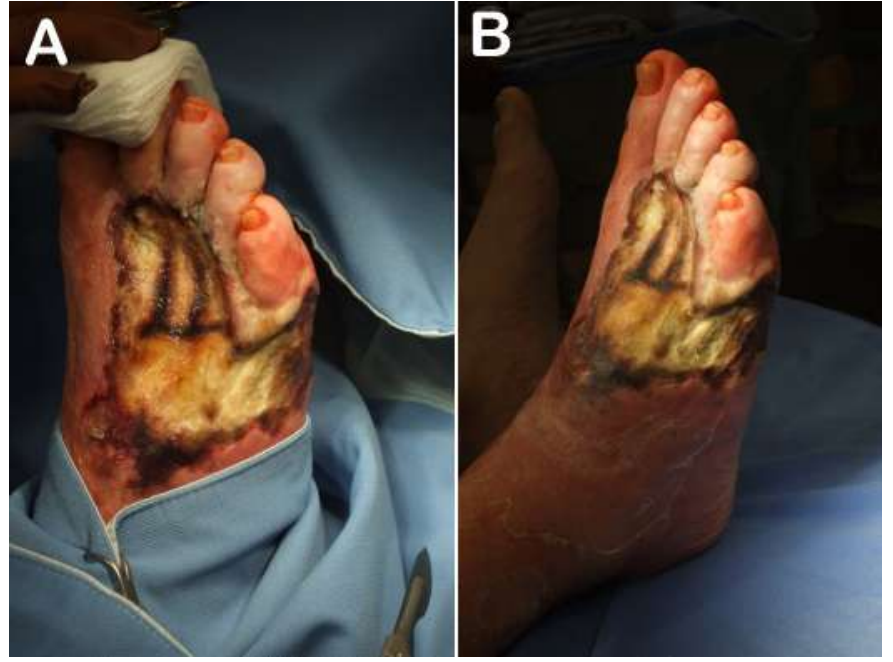

Figure 1. The mid-foot ulcer before first surgical intervention

to the Kings College Hospital in London, $62 \%$ of patients suffer from neuropathic DFS $13 \%$ from a vascular type and $25 \%$ from mixed type DFS. Symptoms of ischemic etiology DFS are rest pain especially during the night, localized in the distal part of the lower extremity. The pain decreases after lowering of the limb and increases with lower limb edema. On the other hand the neuropathic DFS is characterized by cold sensation, numbness, increased skin temperature, visibly engorged veins, muscle tremor, cramps and crushing sensation. In comparison to vascular DFS pain, this one is constant, disseminated, with episodes of massive aggravation. It escalates into allodynia and subsequently disappears after the total nervous disruption. All of those changes are steps that could be indicative of ongoing gangrene or skin ulceration process. The proper treatment protocol is supported by basic laboratory parameters, wound swab culture (in order to identify the main pathogen), as well as confirmation of infection duration and DFS etiology. Prolonged waiting time, and conservative treatment may result in deep fulminant infection possibly leading to sepsis, high limb amputation and death. 5 .13

The efficacy of ulcerative changes treatment was evaluated in many previous publications. Those did not however include aspects of fulminant septic symptoms that often lead 
to amputation. In the case of mixed DFS, deep progressive limb ischemia is probable even in the absence of symptoms. This condition provides consequently a favorable environment for the growth of bacteria, what can then lead to progressive infection, sepsis and often the death of the patient. The modern way to treat deep wound infections is with the use of vacuum therapy (VAC)! 14] In this paper, we present a complex case of combination therapy, in which we failed to rescue the patient's limb.

\section{CASE REPORT}

A 60-year-old patient was admitted to the hospital emergency department due to necrotic lesions of the dorsal surface of the toes as well as dorsal- and the lateral side of the foot. The patient suffered from type II diabetes for an unspecified time period. Outpatient medical treatment consisted of the topical application of a broad spectrum antibiotic ointment. About three weeks after the first symptoms appeared, the patient was admitted to the hospital. Necrotic lesions were defined as stage IV according to the classification of Wagner. Patient concomitantly suffered from hypertension and smoked 30 cigarettes per day for 40 years, leading a sedentary lifestyle. His Body Mass Index was about 32. Pulse was palpable over the femoral arteries, poorly palpable over the right popliteal artery, and not palpable on the arteries of the foot. Ankle Brachial Index was 0.8. Patient was diagnosed with ischemic DFS with dry ulcer with necrosis, swelling and inflammation of the forefoot and midfoot, which did not extend to II and IV toes. This resulted in swelling and excessive calor of the entire foot. See figure 1 .

After hospital admission, we ordered microbiological wound tests, which indicated Pseudomonas aeruginosa infection. Intravenous targeted antibiotic therapy was initiated: Augmentin (at a dose of $2.4 \mathrm{~g}$ per day) and Gentamicin (at a dose of $160 \mathrm{mg}$ per day).

In less than a few hours after admission to the hospital, we were forced to order an urgent angiography - numerous major vascular constriction of the lower limb became apparent. The right popliteal artery in the P2 segment was constricted in $70 \%$, the tibial artery in $80 \%$, and sagittal artery - $90 \%$. These changes were reversed after the application of percutaneous balloon angioplasty of all above-mentioned arteries. Additionally, $75 \mathrm{mg}$ of clopidogrel daily was administered. We were able to achieve a significant improvement in peripheral circulation, pulse over peripheral arteries, as well as improvement of peripheral distal limb's perfusion. See figure 2 .

We then performed a rapid debridement of the ulcer by removing of necrotic and purulent material within the healthy tissues. VAC dressings were applied on such prepared wound bed to remove excessive secretions as well as improve blood circulation and reduce swelling. Dressing changes were performed every 2-3 days. See figure 3

During second dressing change, additional debridement was performed. A noticeably better perfusion of the distal limb tissues was observed. See figure 4.

During third dressing change (nine days since admission) we diagnosed necrosis of the toes III-V. We decided to

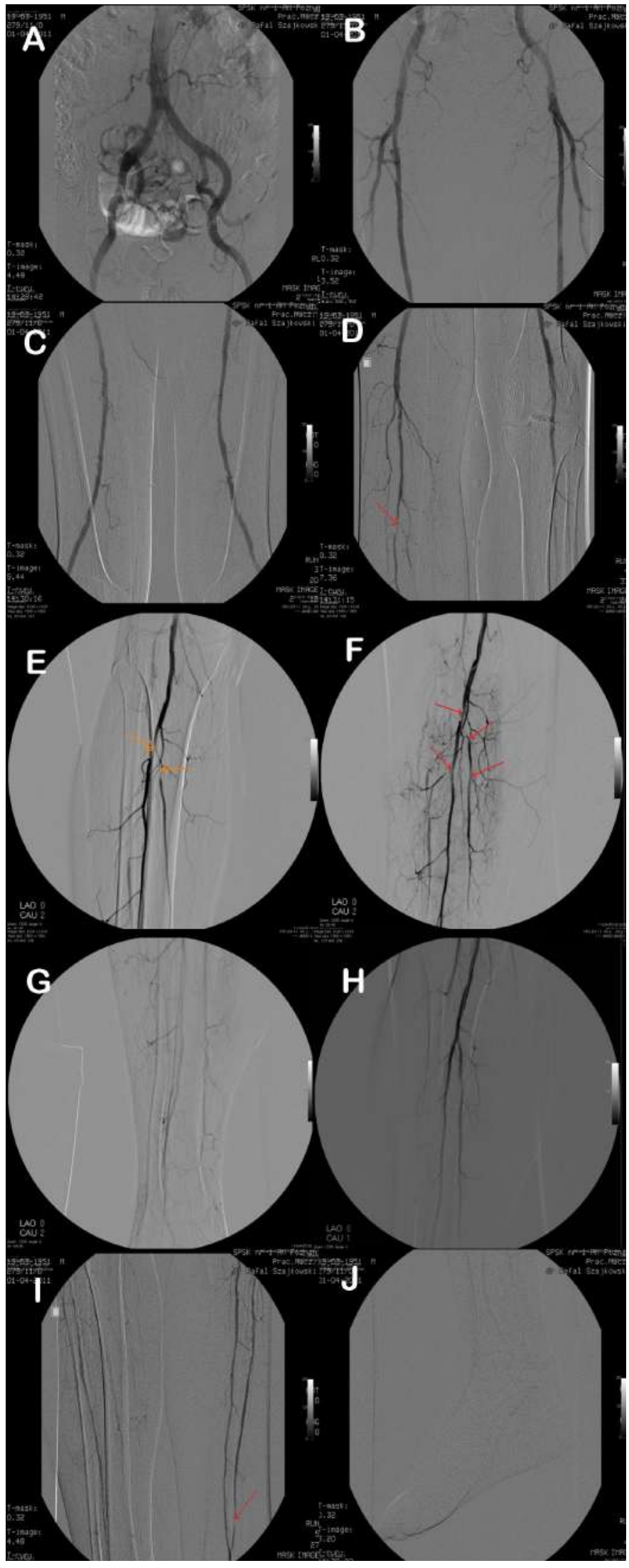

Figure 2. Angiography: arrows show a marked arterial constriction, which was resolved by percutaneous balloon angioplasty. Negligible flow to peripheral arteries is visible. 


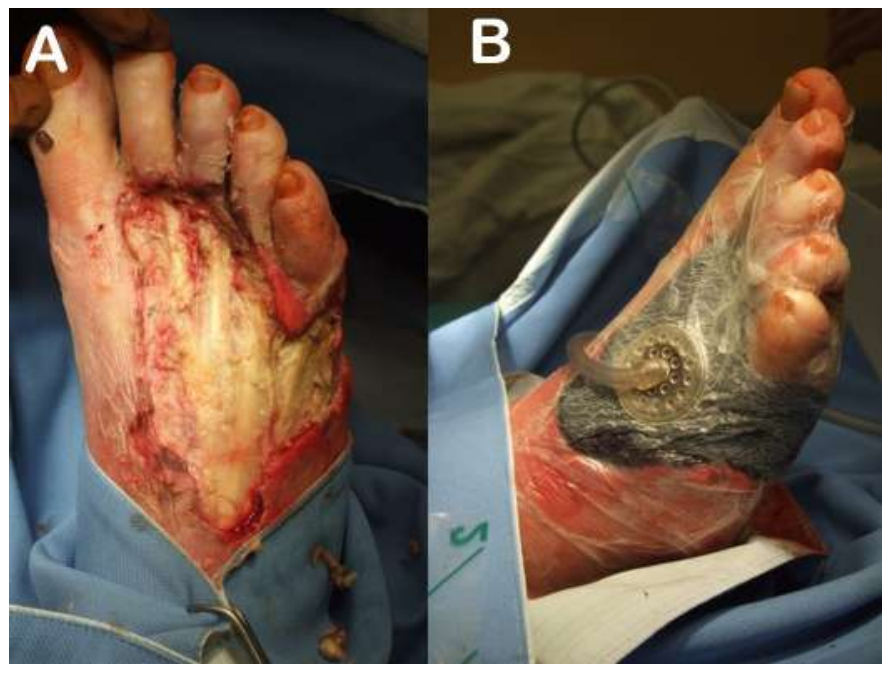

Figure 3. The first fitting of the vacuum dressing, removal of all possibly necrotic tissues.

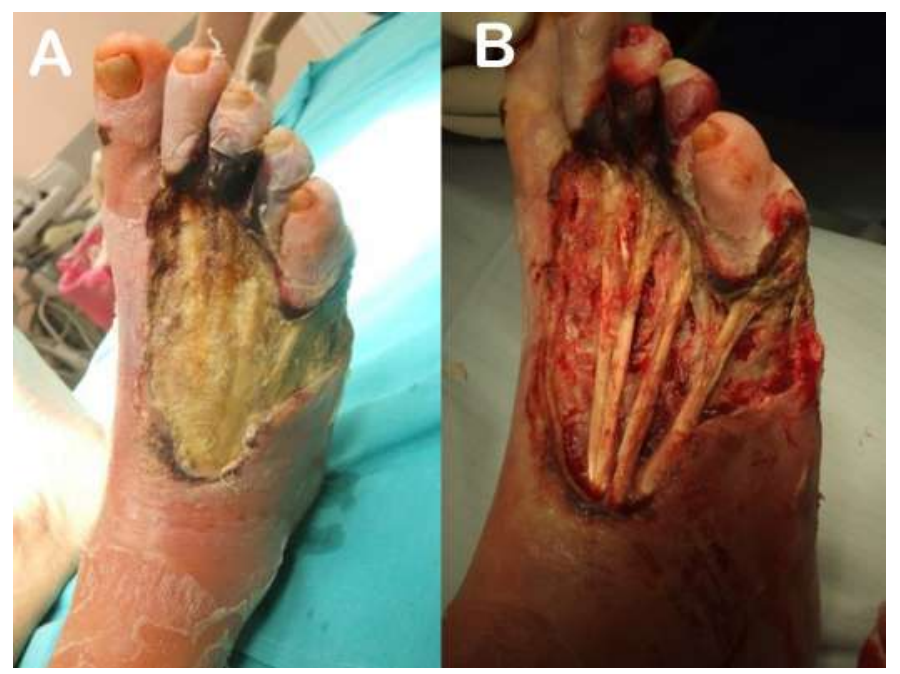

Figure 4. The second debridement of necrotic lesions on the sixth day of admission. Significant improvement in limb blood flow.

amputate these with wide debridement of the ischemic tissues. See figure 5 .

The eleventh day after admission to the hospital, (between the third and fourth dressing change) VAC dressing decompression occurred, which resulted in the accumulation of pus in the deep wound layers. Inadequate resealing of the dressing, conducted by a nurse team, without the doctor's supervision, probably allowed for the rapid development of bacterial outgrowth. The event took place during the weekend, at the time the patient was in an unconditioned room with high interior temperature.

Over the next three days the edema and inflammatory infiltration progressed. Along with these changes hectic fever of up to $40.2^{\circ} \mathrm{C}$, tachypnoea, and fatigue at rest occurred. Laboratory work-up demonstrated an increase in the number of leukocytes to about $18,000 / \mathrm{mL}$ and high C-reactive protein (CRP) level (from $50 \mathrm{mg} / \mathrm{L}$ to about $230 \mathrm{mg} / \mathrm{L}$ within 3 days). Procalcitonin has reached a level of $>400 \mathrm{ng} / \mathrm{mL}$. 4 days after the dressing decompression, consciousness, and cognitive disorders occurred. All these factors including the patient's clinical state pointed to the emergence of a generalized infection and septic shock symptoms. In order to save the patient's life, we were forced to perform a high amputation of the lower limb. See figure 6 .

\section{DISCUSSION}

Undiagnosed or poorly managed diabetes can lead to the development of ischemia, atherosclerosis, or neurological disorders. One of the chronic complications of diabetes is DFS, which affects not only the health of the patient, but it can also threaten his life. Many cases of DFS are accompanied by an infection which very often is multifactorial.2 17,19

During hospitalization, the patient was treated with targeted antibiotics according to AST results. We re-vascularized ischemic tissues, eliminated necrosis out of the wound bed and used vacuum dressings which we changed every 2-3 days. We also evaluated the possibility of wound closure using skin grafts or dermal flap reposition with simultaneous treatment of concomitant diseases which we eventually abandoned.

Microbial cultures of infected leg ulcers often indicate Gram-negative bacteria colonization $(57.2 \%$, Enterococcus, Enterobacteriaceae, Pseudomonas aeruginosa) and Grampositive (42.8\%) mainly Streptococcus and Staphylococcus as well as anaerobic bacteria and fungi 5$]$ 15, 17, 18, 20,22 Statistically, we most often deal with wound colonization by Pseudomonas aeruginosa (in $21.43 \%$ of symptomatic patients) and Staphylococcus aureus (17.86\% of respondents) ${ }^{[4}$ Thus, it is difficult to choose the right antibiotic, without knowing the type of pathogen present in the wound.

In the described case, prolonged prehospital treatment based on broad spectrum antibiotics in insufficient doses was incorrect, which could have favored the accumulation of necrosis. The literature suggests that the risk of amputation increases with the duration of the disease and with each day of conservative treatment. 23

In the case of DFS, changes occur in tunica media, leading to calcification, which causes narrowing of the lumen or even total obstruction of the artery. ${ }^{[2]}$ Balloon angioplasty of the main lower limb arteries improves the blood circulation and nutrient supply to the wound, what reduces the time of treatment. It reduces the risk of wound recurrence while

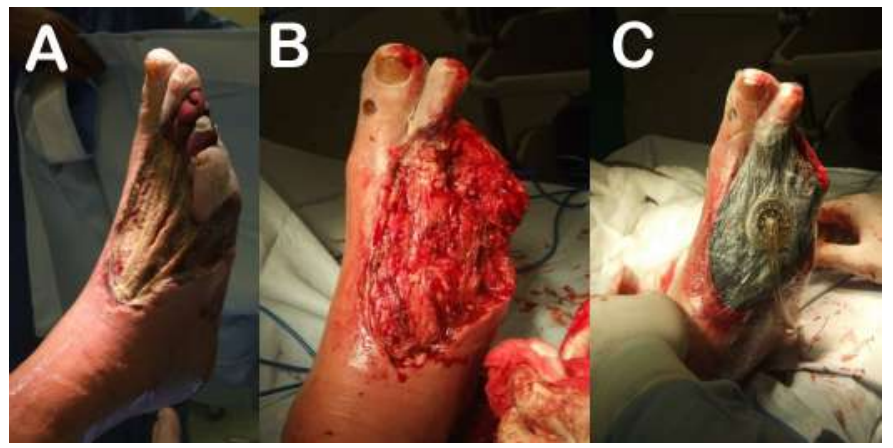

Figure 5. The necessity of II to V toes amputation occurred. Proper blood circulation in the limb visible (b). 


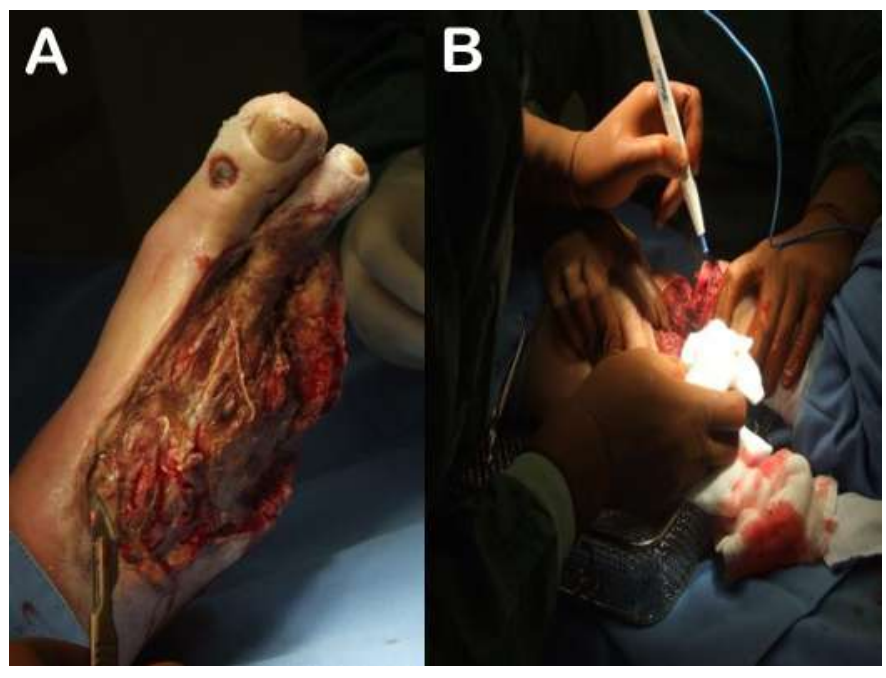

Figure 6. Significant deterioration in the blood supply to the limb (a). One of the stages of limb amputation (b).

endovascular treatment is often the last chance to save the limb from amputation. $3 \sqrt{14}[8,24$ Endovascular treatment begins to gain an important role in the treatment of DFS and should be applied in combination with surgical approach 25

In the above case we were dealing with a mixed type of DFS, with a significantly increased risk of sepsis. Ulcers with a small outer diameter often may mask more serious lesions in the deeper tissues that would require extensive radical debridement. The mean treatment duration of DFS ulcers takes approximately 3-5 months. Implementation of the vacuum dressings changed every 2-3 days, combined with surgical wound debridement has reduced this time to approximately 1 month. ${ }^{17}$ 27] Wachal et al. estimated that the average treatment time using this method is reduced to 19 days. 14

One of the principles of this approach is the close cooperation of all medical staff members, both doctors as well as the nursing staff. The well-trained medical team should understand the phenomena taking place in the ischemic limb and respond quickly in case of vacuum dressing leaks. 13.28 Leaving the wound covered by a sealing film in an unconditioned room where the temperature exceeds $25^{\circ} \mathrm{C}$ will inevitably lead to a rapid outgrowth of bacteria, which can turn into a rapidly progressive sepsis leading to a septic shock.

There is general agreement that the use of VAC dressings improved blood circulation and promotes wound granulation process. Armstrong et al. estimated in their work, that application of negative pressure dressings in patients with leg ulcers and DFS increased the chance of total recovery by $17 \%$ when compared with the group of patients treated conservatively pharmacologically. $13,15,28,30$

It is estimated that about 750,000 people worldwide die each year from complications of severe sepsis or septic shock. Mortality despite the introduction of the latest standards, ranges from $30-60 \%$ of patients. Gierek et al. showed, that in the group of 646 intensive care unit (ICU) patients (during 20082009) $7.0 \%$ were diagnosed with severe sepsis (3 patients) or septic shock (42 patients) and 29 patients died $(57.7 \%) .31$ In Poland, the incidence and mortality of sepsis are significant.
According to the Polish Sepsis Working Group's study, the prevalence of severe sepsis is approximately $14.6 \%$ of patients treated in the ICUs while the diagnosis of septic shock could be made in $6 \%$ of those patients. ${ }^{[2]}$ People who die due to sepsis, are often affected by concomitant diseases: cardiovascular disease, atrial fibrillation, coronary heart disease, hypertension, diseases of the pancreas, chronic renal failure or diabetes.31

In the pathological evolution of septic shock, the symptoms of sepsis are accompanied by hypotension with impaired tissue perfusion. ${ }^{[2]}$ In our patient, about 4 days after vacuum dressing decompression CRP levels, procalcitonin levels and leukocyte numbers significantly increased. We observed respiratory as well as consciousness disorders and drop in blood pressure. Our decision to perform lower limb amputation was due to the ongoing significant deterioration of the clinical condition, and occurrence of the septic shock indicators. By removing the source of infection, clinical state improvement was achieved!32 33

During the Open Diabetes Leadership Forum, which was held in Beijing in 2009, Kofi Annan said: "Throughout the world, the threat of diabetes is ignored and under-funded. Fighting diabetes must be a priority. The problem is so serious that we all need to get involved if we want to prevent the epidemic wave". We agree with these words. Fast action, the right management and adequate training of the medical team are the most important aspects affecting the proper treatment of DFS.

\section{REFERENCES}

[1] M. Kozierska-Rosciszewska, Cukrzyca u osob starszych diagnostyka, leczenie, prewencja powiklan. Zaklad Medycyny Rodzinnej i Medycyny Spolecznosci Lokalnej: Uniwersytet Medyczny w Lodzi.

[2] B. Ducka and K. Strojek, "Rola diabetologa w zapobieganiu rozwojowi stopy cukrzycowej," Przewodnik Lekarza, vol. 4, pp. 43-51, 2007.

[3] Niebieska Ksiega Cukrzycy, Warszawa, 2013.

[4] A. Neneman, M. Deja, H. Kubisiak-Rzepczyk, T. MiroszewskaSobanska, L. Kurek, M. Szarata, and A. Z., "Wplyw cukrzycy na wystepowanie i przebieg owrzodzen podudzi, ze szczegolnym uwzglednieniem zakazen bakteryjnych i grzybiczych," Nowiny Lekarskie, vol. 75 , no. 6 , pp. 505-511, 2006.

[5] A. Korzon-Burakowska and S. Tecza, "Infekcje w przebiegu zespolu stopy cukrzycowej," Diabetologia Praktyczna, no. 2, pp. 92-96, 2005.

[6] M. Eneroth, J. Apelqvist, and A. Stenstrom, "Clinical characteristics and outcome in 223 diabetic patients with deep foot infections," Foot \& Ankle International, vol. 18, no. 11, pp. 716-722, nov 1997. [Online]. Available: http://dx.doi.org/10.1177/107110079701801107

[7] R. E. Pecoraro, G. E. Reiber, and E. M. Burgess, "Pathways to diabetic limb amputation: Basis for prevention," Diabetes Care, vol. 13, no. 5, pp. 513-521, may 1990. [Online]. Available: http://dx.doi.org/10.2337/diacare.13.5.513

[8] L. G. Newman, "Unsuspected osteomyelitis in diabetic foot ulcers," JAMA, vol. 266, no. 9, p. 1246, sep 1991. [Online]. Available: http://dx.doi.org/10.1001/jama.1991.03470090080036

[9] G. E. Reiber, "Risk factors for amputation in patients with diabetes mellitus," Annals of Internal Medicine, vol. 117, no. 2, p. 97, jul 1992. [Online]. Available: http://dx.doi.org/10.7326/0003-4819-117-2-97

[10] M. L. Grayson, G. W. Gibbons, G. M. Habershaw, D. V. Freeman, F. B Pomposelli, B. I. Rosenblum, E. Levin, and A. W. Karchmer, "Use of ampicillin/sulbactam versus imipenem/cilastatin in the treatment of limb-threatening foot infections in diabetic patients," Clinical Infectious Diseases, vol. 18, no. 5, pp. 683-693, may 1994. [Online]. Available: http://dx.doi.org/10.1093/clinids/18.5.683

[11] B. R. Shah and J. E. Hux, "Quantifying the risk of infectious diseases for people with diabetes," Diabetes Care, vol. 26, no. 2, pp. 510-513, feb 2003. [Online]. Available: http://dx.doi.org/10.2337/diacare.26.2.510 
[12] J. Wrobel and J. Connolly, "Making the diagnosis of osteomyelitis the role of prevalence," Journal of the American Podiatric Medical Association, vol. 88, no. 7, pp. 337-343, jul 1998. [Online]. Available: http://dx.doi.org/10.7547/87507315-88-7-337

[13] G. Oszkinis, M. Gabriel, F. Pukacki, and W. Majewski, Leczenie ran trudno gojacych sie. Warszawa: Blackhorse Scientific Publishers, 2006.

[14] K. Wachal, B. Lyszyk, and M. Kozak, "Rola nowoczesnych opatrunkow w leczeniu zespolu stopy cukrzycowej'," Med. Metab: T., vol. 16, no. 1, pp. 88-90, 2012

[15] K. Wachal, K. Karas, M. Stanisic, Z. Krasinski, R. Staniszewski, and G. Oszkinis, "Ocena skutecznosci leczenia chorych z zespolem stopy cukrzycowej po pierwotnej amputacji w zakresie stopy z powodu zmian martwiczych, leczonych technika "otwarta" z zastosowaniem opatrunkow podcisnieniowych'," Acta Angiol., vol. 18, no. Suppl. A p. A48, 2012.

[16] K. Wachal, R. Staniszewski, W. Majewski, K. Pawlaczyk-Gabriel, and B. Lyszyk, Ocena zastosowania terapii VAC u chorych z zespolem stopy cukrzycowej o etiologii niedokrwiennej $z$ dokonanymi zmianami martwiczymi $w$ obrebie tkanek glebokich.

[17] K. Wachal, R. Staniszewski, W. Majewski, and R. Juszkat, "Ocena skutecznosci zabiegow rewaskularyzacyjnych u pacjentow z zespolem stopy cukrzycowej leczonych jednoczesnie terapia vac," Acta Angiol, vol. 16, no. Suppl. A, p. A68, 2010.

[18] M. Gabriel, K. Pawlaczyk, G. Oszkinis, F. Pukacki, P. Checinski, M. Zielinski, and K. Wachal, "Zmiana podatnosci allogenicznych przeszczepow naczyniowych implantowanych w srodowisku zakazonym," Acta Angiol, vol. 11, no. 1, pp. 73-74, 2005.

[19] A. Berent and B. Lipsky, "Zakazenie kosci i stawow w przebiegu stopy cukrzycowej," Medycyna po Dyplomie, vol. 1, pp. 38-52, 2004.

[20] A. Korzon-Burakowska, "Zespol stopy cukrzycowej - patogeneza i praktyczne aspekty postepowania," Choroby Serca i Naczyn, vol. 4, no. 2, pp. 93-98, 2007.

[21] A. Sekowska and E. Gospodarek, "Zakazenie stopy cukrzycowej analiza mikrobiologiczna," Pielegniarstwo Chirurgiczne i Angiologiczne, vol. 4, pp. 119-122, 2010.

[22] [Online]. Available: https://pneumonologia.wum.edu.pl/sites/ pneumonologia.wum.edu.pl/files/sepsa.pdf

[23] E. Wojcik, "Zespol stopu cukrzycowej pod nadzorem," Diabetologiaonline.pl. [Online]. Available: http://diabetologiaonline. pl/pielegniarka_artykuly.info.207.html

[24] M. Sojka, T. Jargiello, A. Wolski, M. Gornik, K. Karska, and M. Szczerbo-Trojanowska, "Leczenie wewnatrznaczyniowe zespolu stopy cukrzycowej," Postepy Nauk Medycznych, no. 5, pp. 428-433, 2012.

[25] F. B. Pomposelli, N. Kansal, A. D. Hamdan, A. Belfield, M. Sheahan,
D. R. Campbell, J. J. Skillman, and F. W. Logerfo, "A decade of experience with dorsalis pedis artery bypass: Analysis of outcome in more than 1000 cases," Journal of Vascular Surgery, vol. 37, no. 2, pp. 307-315, feb 2003. [Online]. Available: http://dx.doi.org/10.1067/mva.2003.125

[26] M. S. Conte, D. F. Bandyk, A. W. Clowes, G. L. Moneta, L. Seely, T. J. Lorenz, H. Namini, A. D. Hamdan, S. P. Roddy, and M. Belkin, "Results of PREVENT III: A multicenter, randomized trial of edifoligide for the prevention of vein graft failure in lower extremity bypass surgery," Journal of Vascular Surgery, vol. 43, no. 4, pp. 742-751.e1, apr 2006. [Online]. Available: http://dx.doi.org/10.1016/j.jvs.2005.12.058

[27] K. Wachal, W. Majewski, A. Kopydlowska, Z. Turowiecka, E. Wojtasinska, K. Ciepluch, K. Zawilska, M. Cieszko, and N. Majewska, "Czestosc wystepowania pierwotnego zespolu antyfosfolipidowego u chorych z obwodowymi zaburzeniami w tetnicach konczyn dolnych lub gornych," Acta Angiol, vol. 14, no. Suppl. A, p. A47, 2008.

[28] I. Robaczewska, M. Filanowicz, and B. Cegła, "Pielegniarskie działania oparte na stosowaniu specjalistycznych opatrunków ratujacych stope cukrzycowa," Pielegniarstwo Polskie, vol. 1, no. 51, pp. 41-48, 2014.

[29] G. Rosiński, "Profilaktyka i leczenie zakażeń stopy cukrzycowej stanowisko polskich ekspertów," Zakazenia, no. 1, pp. 94-99, 2006.

[30] G. Rosinski, "Leczenie zespolu stopy cukrzycowej (zsc)," Przewodnik Lekarza, no. 3, pp. 58-64, 2005.

[31] D. Gierek, M. Kuczera, J. Dabek, D. Pilat, and A. Kurtok-Nowak, "Analiza leczenia chorych z ciezka sepsa na oddzialach anestezjologii i intensywnej terapii górnoślaskiego centrum medycznego," Anestezjologia Intensywna Terapia, vol. XLIII, no. 1, pp. 22-28, 2011.

[32] N. Wrzesinska, "Wstrzas septyczny." [Online]. Available: http: //wylecz.to/pl/choroby/uklad-krazenia/wstrzas-septyczny.html

[33] T. Targowski and T. Plusa, "Leczenie i profilaktyka sepsy," Przewodnik Lekarza, no. 1, pp. 195-197, 2008.

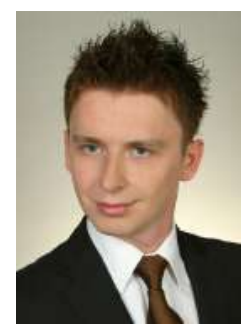

Krzysztof Karaś, M.D. studied in the Poznań University of Medical Sciences (PUMS) and in 2011 receieved the Medal for Scientific and Social Work, given by the President of PUMS

He previously studien at the Christian Albrecht's University, Faculty of Medicine, Kiel, Germany (as an ERASMUS student) and Univeritätsklinikum Schleswig-Holstein Klinik fur Herz Und Gefäßchirurgie

Since 2013 he works at the Surgical Deprtment in the Public Hospital in Gniezno (Poland). He is currently doing his Ph.D. and his hobbies are extreme sports, sky diving, long-distance cross country running and Krav Maga. 